\title{
Pendampingan Penyusunan Laporan Keuangan Pada Badan Usaha Milik Desa (Bumdes) Lestari Desa Bandung Kecamatan Diwek Jombang
}

\author{
Agus Taufik Hidayat ${ }^{1}$, Lilik Pujiati ${ }^{2}$, Nurul Hidyati ${ }^{3}$, \\ Suluh Agus Hendrawan ${ }^{4}$, Sugeng Suprapto ${ }^{5}$, Nurali $^{6}$ \\ agustaufik.stiepgridw@gmail.com ${ }^{1}$, lilik.pujiati@yahoo.com², \\ nhdewantara@gmail.com ${ }^{3}$, kanggehendra@ $@$ yahoo.com $^{4}$, \\ gengulum@gmail.com ${ }^{5}$, noer.aly@gmail.com ${ }^{6}$
}

\section{STIE PGRI Dewantara Jombang}

\begin{abstract}
Abstrak
Salah satu kewajiban dosen sebagaimana yang diamanatkan Tri Dharma Perguruan Tinggi adalah melakukan pengabdian kepada masyarakat. Untuk itu, tim penulis melakukan bentuk pengabdian kepada masyarakat dalam bentuk pendampingan penyusunan laporan keuangan pada Badan Usaha Milik Desa (BUMDes) Lestari sebagai mitra binaan yang bergerak di bidang usaha jasa berupa pengelolaan pasar desa Bandung. Kesulitan yang dialami mitra adalah penyusunan laporan keuangan serta pencatatan transaksinya belum rapi. Melalui serangkaian kegiatan pendampingan yang dilakukan bersama mitra, diperoleh kemajuan sehingga mitra binaan bisa melakukan pencatatan transaksi secara rapi dan penyusunan laporan keuangan sesuai standar akuntansi.
\end{abstract}

Kata kunci: BUMDes, Pencatatan transaksi, laporan keuangan

\begin{abstract}
One of the obligations of lecturers as mandated by Tri Dharma Perguruan Tinggi is to serve the people. To that end, the authors team performs a form of devotion to the community in the form of mentoring the preparation of financial statements on BUMDes Lestari as a partner built in the field of business services in the form of village market management Bandung. Difficulties experienced by partners is the preparation of financial reports and transactions not yet tidy. Through a series of mentoring activities undertaken with partners, progress is being made so that the built partners can record the transactions in a neat manner and the preparation of financial statements according to accounting standards.
\end{abstract}

Keywords: BUMDes, Transaction recording, financial statements

\section{A. Pendahuluan}

\section{Latar Belakang}

Upaya pemerintah dalam pengembangan basis ekonomi di pedesaan sudah semenjak lama dijalankan. Salah satu program yang diadakan oleh pemerintah adalah pendirian Badan Usaha Milik Desa (BUMDes). Badan usaha ini sesungguhnya telah diamnatkan di dalam UU No. 32 Tahun 2004 tentang Pemerintahan Daerah (bahkan oleh undang-undnag sebelumnya, UU 22/1999) dan Peraturan Pemerintah (PP) No. 71 Tahun 2005 Tentang Desa. Pendirian badan usaha tersebut harus disertai dengan upaya penguatan kapasitas dan didukung oleh kebijakan daerah (Kabupaten/Kota) yang memfasilitasi dan melindungi usaha ini dari ancaman persaingan para pemodal besar.

Pendirian BUMDes didasarkan pada kebutuhan dan potensi desa, sebagai upaya peningkatan kesejahteraan masyarakat. Berkenaan dengan perencanaan dan pendiriannya, BUMDes dibangun atas prakarsa (inisiasi) masyarakat, serta mendasarkan pada prinsip- prinsip kooperatif, partisipatif, transparansi, emansipatif, akuntable, dan sustainable dengan mekanisme member-base dan self-help. Oleh karena itu, perlu upaya serius untuk menjadikan pengelolaan badan usaha tersebut dapat berjalan secara efektif, efisien, professional dan mandiri. 
BUMDes merupakan wahana untuk menjalankan usaha di desa. Apa yang dimaksud dengan "usaha desa" adalah jenis usaha yang meliputi pelayanan ekonomi desa seperti:

a. Usaha jasa keuanganm jasa angkutan darat dan air, listrik desa, dan usaha sejenis lainnya;

b. Penyaluran Sembilan bahan pokok ekonomi desa;

c. Perdagangan hasil pertanian meliputi tanaman pangan perkebunan peternakan perikanan, dan agrobisnis;

d. Industri dan kerajinan rakyat

Pertanggungjawaban pelaksanaan BUMDes diatur dalam Pemendes No. 4 Tahun 2015 Pasal 31 yang menyatakan bahwa "Pelaksana Operasioanal melaporkan pertanggungjawab pelaksanaan BUMDes kepada Penasehat yang secara ex-officio dijabat oleh Kepala Desa".

Keikutsertaan STIE PGRI Dewantara dalam pendampingan BUMDes dimaksudkan mampu membantu mewujudkan tata kelola badan usaha sesuai dengan peraturan yang ada. Adapun bentuk kegiatannya bervariasi menyesuaikan kondisi masing-masing BUMDes. Terutama dalam bidang Akuntansi dan Manajemen.

\section{Profil BUMDes LESTARI Desa Bandung}

BUMDes Lestari yang terletak di desa Bandung Kecamatan Diwek, Jombang adalah mempunyai jenis usaha pengelolaan pasar desa Bandung. Bumdes Lestari sudah berkembang dengan baik. Struktur dan AD/ART telah tersusun sangat baik. Proses penyusunan Struktur Organisasi dan AD/ART telah disepakati bersama dalam rapat rutin baik oleh perangkat Desa maupun Pengurus yang ditunjuk. AD/ART telah disepakati sebagai panduan kegiatan untuk masa tiga tahun. Ada tidaknya perubahan dalam AD/ART juga telah disepakati bisa diadakan berdasarkan hasil evaluasi terinci dari laporan oleh pengurus BUMDes dan atau perangkat desa.

\section{B. Tinjauan Pustaka}

\section{Dasar Hukum Pendirian BUMDes}

Pendirian BUMDes dilandasi oleh Undang-Undang no 32 tahun 2004 tentang Pemerintahan Daerah dan PP no 72 tahun 2005 tentang Desa. Secara rinci landasan hukum tersebut yakni pada UU no 32 tahun 2004 tentang Pemerintah Daerah, tepatnya pada pasal 213 ayat 1 yang berbunyi " Desa bisa mendirikan badan usaha milik desa sesuai dengan kebutuhan dan potensi yang dimiliki desa". Sedangkan untuk PP no 72 tahun 2005 tentang Desa ada beberapa pasal yakni :

Pasal 78 yang menjelaskan tentang beberapa hal antara lain :

1. Dalam meningkatkan pendapatan masyarakat dan desa, pemerintah desa bisa mengatasinya dengan mendirikan badan usaha milik desa yang sesuai dengan kebutuhan dan potensi desa.

2. Pembentukan badan usaha milik desa ditetapkan dengan peraturan desa yang berpedoman pada peraturan perundang-undangan.

3. Bentuk badan usaha milik desa harus berlandaskan pada hukum.

Pasal 79 yang memaparkan beberapa penjelasan mengenai :

1. Badan usaha milik desa meruupakan usaha yang dikelola oleh pemerintah desa.

2. Permodalan badan usaha milik desa berasal dari :

- Pemerintah desa

- Tabungan masyarakat

- Bantuan pemerintah Pusat, pemerintah Provinsi, pemerintah Kabupaten/ Kota. 
- Pinjaman dari berbagai pihak

- Kerjasama dan bagi hasil dengan pihak lain.

3. Kepengurusan badan usaha milik desa terdiri dari pemerintah Desa dan masyarakt.

Pasal 80 menjelaskan tentang beberapa hal, yakni :

1. Badan usaha milik desa memiliki wewenang untuk melakukan peminjaman sesuai dengan peraturan perundang-undangan yang ada.

2. Pinjaman bisa didapan badan usaha milik desa setelah mendapat persetujuan dan izin dari BPD

Pasal 81 memaparkan tenag beberapa hal, antara lain :

1. Ketentuan tentang mengenai tata cara pembentukan dan pengelolaan badan usaha milik desa diatur dalam peraturan daerah Kabupaten / Kota.

2. Peraturan daerah Kabupaten/ kota memuat beberapa hal penting, antara lain :

- Bentuk badan hukum

- Kepengurusan

- Hak dan kewajiban

- Permodalan

- Bagi hasil usaha atau keuntungan

- Kerjasama dengan pihak ke-3

- Mekanisme pengelolaan dan pertanggungjawaban

\section{Ciri - Ciri BUMDes}

Ada beberapa ciri BUMDes yang membedakannya dengan organisasi bisnis yang lain yaitu:

1. Kekuasaan penuh di tangan desa, dan dikelola bersama masyarakat desa

2. Modal bersama yakni bersumber dari desa dan masyarakat, dilakukan dengan cara penyerataan modal.

3. Menggunakan falsafah bisnis yang berakar dari budaya lokal untuk melakukan kegiatan operasional. Proses operasionalisasi ini di kontrol bersama oleh BPD,Pemerintah Desa dan anggota masyarakat.

4. Untuk bidang yang dipilih bagi badan usaha desa disesuaikan dengan potensi dan informasi pasar.

5. Keuntungan yang diperoleh dari produksi dan penjualan ditujukan untuk meningkatkan kesejahteraan anggota dan masyarakat desa melalui kebijkan desa.

6. Pemberian fasilitas dan pengawasan dilakukan oleh Pemerintah Provinsi, Pemerintah Kabupaten, dan Pemrintah Desa.

\section{Tujuan Pendirian BUMDes}

Tujuan didirikannya BUMDes oleh pemerintah adalah

1. Meningkatkan perekonomian masyarakat desa

2. Meningkatkan pendapatan masyarakat desa

3. Mengoptimalkan potensi sumber daya alam untuk kebutuhan masyarakat

4. Menjadi alat pemerataan dan pertumbuhan ekonomi desa.

Melihat dari ciri dan tujuan pendirian BUMDes sebagaimana dijelaskan diatas, maka disimpulkan bahwa BUMDes adalah sebuah wujud dari pengelolahan ekonomi produktif desa yang dilakukan secara kooperatif, partisipatif, emansipatif, transparansi, akuntabel dan sustainable. KArena itu, dalam pengelolaannya BUMDes tidak bisa dikelola secara asal-asalan namun diperlukan pengelolahan yang serius dan professional, agar bisa berjalan secara mandiri, efektif dan profesional.

\section{Jenis Usaha BUMDes}

Jenis-jenis usaha yang ada di BUMDes, antara lain : 
1. Serving, yaitu salah satu jenis BUMDes yang fokus menjalankan bisnis sosial yang melayani warga bisa disebut dengan pelayanan publik yang ditujukan pada seluruh masyarakat.

2. Banking, yaitu jenis usaha yang berfokus pada bisnis keuangan yakni dengan memenuhi kebutuhan keuangan masyarakat desa.

3. Renting, yaitu jenis usaha yang berfokus pada bidang penyewaan yakni dengan melayani semua masyarakat desa yang membutuhkan persewaan dalam upaya memenuhi kebutuhan hidupnya.

4. Brokering, yaitu menjadi brokering adalah perantara, jadi jenis BUMDes ini bisa disebut dengan lembaga perantara yang menghubungkan antara satu pihak dan pihak lainnya yang memiliki tujuan sama.

5. Trading, yaitu salah satu jenis usaha di BUMDes yang memfokuskan usahanya dalam produksi dan berdagang barang-barang tertentu dalam sebuah pasar dengan skala yang luas untuk memnuhi kebutuhan masyarakat.

6. Holding, yaitu salah satu jenis badan usaha yang sering disebut dengan usaha bersama atau adalah sebuah unit dari unit-unit usaha yang ada di desa, dimana masing-masing unit yang berdiri sendiri-sendiri, yang diatur dan ditata sinerginya oleh BUMDes agar tumbuh dan berkembang bersama.

7. Contracting, yaitu usaha kemitraan yang dilaksanakan oleh unit usaha dalam BUMDes bekerjasama dengan Pemerintah Desa atau pihak yang lainnya (Anonim, 2017)

\section{Metode Pelaksanaan Kegiatan}

Pelaksanaan kegiatan pendampingan tata kelola di BUMDes Desa Bandung, Kecamatan Diwek, Kabupaten Jombang merupakan salah satu bentuk pelaksanaan pengabdian masyarakat yang merupakan serangkaian kegiatan Tri Dharma Perguruan Tinggi. STIE PGRI Dewantara Jombang, sebagai salah satu perguruan tinggi terkemuka di Jombang sudah selayaknya untuk terus sadar akan isu- isu lingkungan sekitar, dalam hal ini adalah isu ekonomi sosial, salah satunya yang berkaitan dengan Badan Usaha Milik Desa. Kegiatan pendampingan BUMDes dilaksanakan dalam kurun waktu 1 (satu) tahun yang dimulai pada semester gasal 2016/2017 hingga semester genap2016/2017. Untuk wilayah desa Bandung, pendampingan dilakukan oleh dua orang dosen yaitu Ibu Ratna Dwi Jayanti, SE., MM. dan Ibu Lilik Pujiati, SE., MSA.

\section{Hasil Kegiatan}

Kegiatan pelaksanaan pendampingan BUMDes dijabarkan dilaksanakan dalam bentuk kunjungan resmi ke kantor Bumdes yang terletak di kantor desa Bandung serta konsultas via telefon.

Pada kunjungan awal/observasi awal, kegiatan difokuskan untuk mengetahui profil, struktur organisasi dan jenis kegiatan BUMdes. Dari hasil observasi diketahui bahwa jenis kegiatan, struktur dan pengurus telah ditentukan dengan jelas, tetapi pengurus belum bisa menunjukkan bukti dokumentasi, karena dokumentasi AD/ART belum tersedia. Struktur organisasi secara tertulis belum tampak di kantor BUMDes. Selain itu, team pendamping menemukan bahwa bukti pembelian pasar desa yang menjadi kegiatan utama BUMDes juga belum tersedia.

Dari segi pencatatan transaksi keuangan /pembukuan. Pembukuan hanya berupa buku kas dan baru dimulai pada tanggal 20 Maret 2016. Sistim pencatatan transaksi dilaksanakan secara manual dan komputer (Ms.Excel) sebagai pendamping. Namun 
dari obeservasi awal, karyawan BUMDes mengakui bahwa masih mengalami kesulitan dalam pengoperasian MS. Excel, sehingga yang utama masih mengandalkan pencatatan manual. Hal ini lazim dialami beberapa unit usaha yang dimiliki pemerintah desa (Mutiarni R, 2017), tidak hanya di BUMDes Lestari. Selain itu, dari hasil observasi awal tersebut, diketahui terdapat selisih saldo keluar yang ada di buku dengan yang tertulis di komputer.

Dari hasil observasi tersebut, maka tim pendamping menentukan rencana kerja untuk selanjutnya. Tim akan memastikan kelengkapan data atau dokumen BUMDes. Selain itu, tim juga akan menyusun standar operasional perusahaan (pengaturan tentang sistem dan alur kegiatan antara pasar desa dan pelaporannya ke BUMDes). Tim pendamping akan memberikan pelatihan pembukuan kepada pengurus BUMDes. Agar lebih memudahkan pekerjaan untuk selanjutnya, tim akan membuat daftar akun yang sesuai dengan ETAP.

Dari hasil obeservasi awal sebagaimana disebutkan diatas, selanjutnya tim pendamping mulai melakukan beberapa perbaikan dan pelatihan sesuai kondisi yang dibutuhkan. Tim melakkukan pelatihan pembukuan /pencatatan transaksi menggunakan Excel yang sudah dikelola sedemikian rupa sehingga karyawan BUMDes bisa mengentry/memasukkan transaksi harian dan laporan keuangan sederhana akan otomatis tersaji (Mutiarni, R., Utomo, L. P., \& Zuhroh, S. 2017)

Selain itu, tim pendamping juga membuat draft tentang ketentuan dan prosedur kegiatan di pasar dan pertanggung jawabannya ke BUMDes.

Setelah melakukan pelatihan pemanfaatan Microsoft Excel (Ms. Excel) beberapa kali dan mitra dianggap telah mampu, selanjutnya tim pendamping memberikan pemahaman tentang tiga laporan keuangan yaitu laporan laba/rugi, neraca dan arus kas yang merupakan standar pelaporan kuangan untuk akuntansi perusahaan jasa.

Untuk pelatihan pembuatan laporan keuangan, tim pendamping perlu mengulang/melakukan beberapa kali. Hal ini karena mitra belum pernah mendapat pelatihan serupa sebelumnya. Namun setelah melewati beberapa kali latihan, mencoba memasukkan transaksi sendiri, tim melihat bahwa mitra telah mampu untuk melanjutkan sendiri sistim pencatatan transaksi hingga penyajian laporan keuangan pada bulan bulan berikutnya.

Namun demikian, tim pendamping bersifat terbuka, apabila di masa mendatang petugas/karyawan Bumdes Lestari masih membutuhkan bantua, tim akan dengan senang hati memberikan bantuan.

\section{E. Penutup}

Dari hasil pendampingan BUMDes di desa Bandung, Kecamatan Diwek pada saat observasi awal disimpulkan bahwa masih terdapat banyak kelemahan dan keterbatasan, sehingga memerlukan pendampingan untuk perbaikan. Keterbatasan itu antara lain: 1) Kegiatan pengelolaan pasar desa belum berjalan dengan transparan dilihat dari sisi pembukuan; 2) Pengurus inti BUMDes juga belum mengetahui posisi aset pasar per tanggal 2017; 3) Penentuan tarif retribusi pasar dan sewa kios belum jelas; 4) Bagi hasil atau pertanggung jawaban pasar ke BUMDes juga belum jelas; 5) Sistem penggajian untuk pengurus BUMDes belum jelas; 6) Belum terampilnya pengurus BUMDes terhadap teknologi komputer yang bisa digunakan di kantor BUMDes, sehingga menghambat kelancaran input pembukuan dan 7) Pencatatan transaksi yang masih terus membutuhkan pelatihan sehingga bisa memenuhi standar akuntansi yang dipakai dan peraturan pelaporan BUMDes. 
Setelah melalui program pendampingan yang dilakukan oleh tim, maka mitra binaan (BUMDes Lestari) telah mencapai beberapa kemajuan. Namun demikian, pendampingan tersebut tidak bisa berhenti setelah kegiatan selesai. Disarankan, pemerintah desa Bandung untuk lebih proaktif melakukan konsultasi kepada tim pendamping atau pihak lain yang kompeten, agar BUMDes Lestari lebih maju dan berkembang.

\section{DAFTAR PUSTAKA}

Anonim. (2017, Januari 20). Dosen Ekonomi. Retrieved Maret 3, 2018, from Dosen Ekonomi Web site: https://dosenekonomi.com/ilmu-ekonomi/bumn/badanusaha-milik-desa , Peraturan Pemerintah Nomor 60 tahun 1959

, Undang-undang Nomor 10 Tahun 1998 tentang Perubahan Atas UndangUndang Nomor 7 Tahun 1992 tentang Perbankan Undang-Undang Republik Indonesia Nomor 17 Tahun 2012 tentang perkoperasian

Undang-undang Republik Indonesia Nomor 25 Tahun 1992 Tentang Perkoperasian

Mutiarni, R., Utomo, L. P., \& Zuhroh, S. (2017). Pendampingan Pencatatan Transaksi Keuangan Pada Koperasi Bunga Harapan Desa Ceweng. Comvice: Journal Of Community Service, 1(1), 33-38.

Mutiarni, R. (2017). Implementasi Electronic Data Processing Pada Koperasi Wanita. Eksis: Jurnal Riset Ekonomi dan Bisnis, 12(2 Okt), 135-148. 